\title{
たわみ性地下埋設管の室内実験 \\ LABORATORY EXPERIMENTS ON THE UNDERGROUND FLEXIBLE PIPE
}

\section{湯 浅 欽 史* \\ By Yoshichika Yuasa}

\section{1.はじめに}

この実験は,すでに土朴学会論文集 No. 83 に発表し た実験に引き続き，1962 年夏，東京大学土質研究室に 招いて著者が行なったものである。暗きょ一般の問題点 と M.G. Spangler の理論の紹介拉よび批判については, それを参照されたい（以下，前論文と略す)。また，半 円筒アーチの応力については, 37 年度土木学会年次学 術講演会に尔いて発表した。今回発表する論文は, とく に flexible pipe を直接目標とした模型実験に関するも のである。

たわみ性暗きょが剛性暗きょと異なった取り扱いが必 要となる点は, 暗きょに作用する側圧が決定的な重要性 をもっていることである。たわみ性暗きょはそれ個有の 強度よりさしら，周囲の土が暗きょに括よぼす圧力を均 等化することによって, 構造物としての強度が期待しう るものである。空気中で上下圧力加えられるならきわ めて小さな荷重しかとりえない薄肉鋼管も, 土中に埋設 されているなら, 管の側方へのたわみが土の反力を誘起 し，ある程度以上の管の変形はさまたげられ，かなり大 きな鉛直荷重にも耐えることができる。それゆえ, 側方 反力の大きさとその性質を知ることがたわみ性暗きょ個 有の問題としては中心課題となり, 力のみでなく变形が 大きな役割を演じる。この点についての認識が従来不十 分であったと考えられるので, この論文の強調点になっ ている。

そこで, 実験データの整理と解析の中心は, 鋼製円管 という力学的性質のよく知れた構造物を取り扱い，その ひずみや変形え直接対象としながら円管周囲の土の性質 を解明していく, ということにある。問題は

A. 円管の応力状態を知ること

B. 冈管の变瑮と土圧との関係加ら, 土の力学的性質 卆知ること

の 2 つ一応わけられる。A. は埋設管の設計に直接役 立ちうる。 B. は“変位する壁”の土拄論（たとえば， シートハイルの土圧）という現在的問題と共通の钼点 をもっているだけでなく, 実用上不明な点の多かったコ ルゲートパイプの問題への一つの理論的資料とするこ とができる。また，この点は Spangler の理論の弱点の 一つにもなっている。

* 正員 工博 法政大学工学部
たわみ性埋没管について Spangler は Trans. of ASCE, vol. 113, pp. 340〜343 の中でつぎのように述 ベている。まず剛性暗きょとの差異としてたわみ量で破 壊が支配されることをあげ，暗きょにかかる荷重を知れ ば弾性限界内では曲げ理論から十分正確にたわみ量を計 算しうることをのべ,ついで多数の現場実験の結果から つぎのような結論を導いている。

(1) 鉛直圧力は Marston の理論で計算でき, 等分 布荷重とみなせる。

（2）鉛直反力は支承幅全体にわたって一様に分布す る。

（3）水平反力は parabolic に管中央 $100^{\circ}$ にわたっ て分布し，その最大圧力は土の受働抵抗係数に水 平半径のたわみ量を乗じたものである。

（4）以上の結果より, 水平たわみ量は次式で表わさ れる。

$$
\Delta=F_{d} \frac{F_{k} W_{c} r^{3}}{E I+0.061 \epsilon r^{4}} \text { (10.(2) 参照) }
$$

$F_{d}$ : deflection lag factor $\epsilon$ : 土の受働抵抗係数

$F_{k}$ : bedding constant $r$ : 円管の半径

$W_{c}$ : 鈖直荷重 $E I:$ 円管の曲げ剛性

そして，€の性質がまだ明らかにされていないことをこ とわり，土質による $\epsilon$ の值の変化に説明を加えている。 続いて $F_{d}$, settlement ratio $\delta$ (円管と土との相対変位 量を円管隣接部の土の圧縮量で除したもの)，千が相互 に密接に関連していること, 施工条件が円管の強度に括 よぼす影響の重要性を強調している。

Spangler の理論を再検討することをふくめ，この実 験で明らかにしたいと思う事項はつぎのようなものであ る。

（1）円管に作用する鉛直圧力の分布状態を推定す る。

（2）円管に作用する側圧の大きさととの分布形を推 定する。これは理論と実際との画面から興味があ る。

（3）土の圧力係数を知ること。いろいろな物理量が 土の変位と圧力の関係にどう効いてくるか, 何に よって砂の圧力が支配されているか。

（4）たわみ性暗きょの設計原理をどのような点に求 めるべきか, その方向をさぐる。

これらの課題を解くために, 比較的均一な条件をえやす 
図一1実験装置全体図

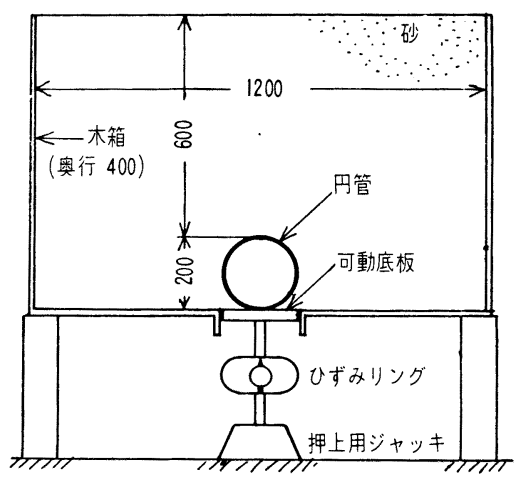

い室内模型を用いた。円管の円周にそって抵抗線ひずみ 計をはり，円周にそった管のひずみ分布を調べ，それを 中心洘察を進める。

\section{2. 実験 概 要}

実験装置と実験方法の詳細は前論文を参照されたい。 図一1 のような木箱に粒径が $0.8 \mathrm{~mm}$ 程度にそろった 気乾状態の砂をつめる。木箱の中央底部の可動底板は上 下に動かすことができ，ひずみリングを介して押上用シ ャッキによって支党られている。円管性肉厚 $2 \mathrm{~mm}$ の鋼 板を外径 $200 \mathrm{~mm}$ にまるめ, 下端を 2 列のボルト（計 18 本）と一枚の座金板によって可動底板にとりつけた ものである。この底板上面とは, 弦長 $50 \mathrm{~mm}$ の凹円筒 面を作り円管を受けている(図一2, bedding angle は 約 $28^{\circ}$ )。ストレィン ゲージは円管の中央断面内周にそ って添付した。 $30 \mathrm{~mm}$ 間隔で 19 枚, ゲージの番号は頂 部を No. 10 とし左右対称飞 No. 1 9, No. 11 19 とする。最上部のゲージ No. 9, No. 19 と座金端との 円周上の距離は $14 \mathrm{~mm}$ となる(図一3)。

補足実験では、木箱の前面の円管があたる部分を切り 抜き，円管内ルダィヤルゲージを 3 個設置した。それ そよって管の半径の変化を直接測定した。

砂高は管頂から砂表面まで $60 \mathrm{~cm}$ で, ゆるづめの場 合と振動を与兄て締固めた場合との 2 種の状態で実験を 行なった。ジャッキによって円管を砂中に押し上げるに したがい, 押上量 $\Delta_{0}$ がつぎの值のときに各計器の読み をとった。単位は $\mathrm{mm}_{\text {。 }}$

ゆるづめ砂： $0,0.1,0.2,0.4,0.7,1,1.5,2,2.5,3$ ， $4,5,6,7,8,10,12$

かたづめ砂: $0,0.05,0.1,0.2,0.4,0.7,1.0,1.5,2.0$, $2.5,3.0,3.5,4.0,4.5,5.0$

その後, 円管を下げもどして順次測定を行なったが，も ぞりの過程についてはいっさい省略する。以上の実験の ほかに, 砂高を $20 \mathrm{~cm}, 40 \mathrm{~cm}$ にしたもの, 砂表面に載 荷（偏心荷重もふくむ）したものについても実験したが 省略する。

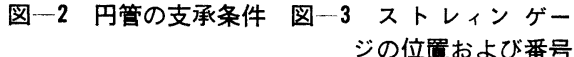

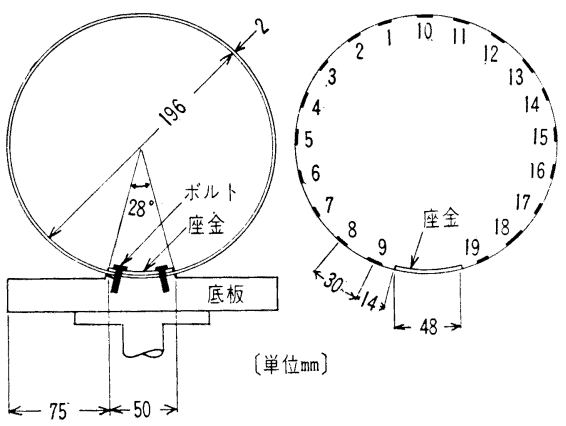

つぎに生デー タの一例学図 -4 亿示す。図 中の点と破線は すべて補足実験 のゆる゙め砂の 場合の央測值で ある。ストレィ ンゲージはNo. 10 (管頂) のみ 図-4 生データの例（ゆるづめ砂）

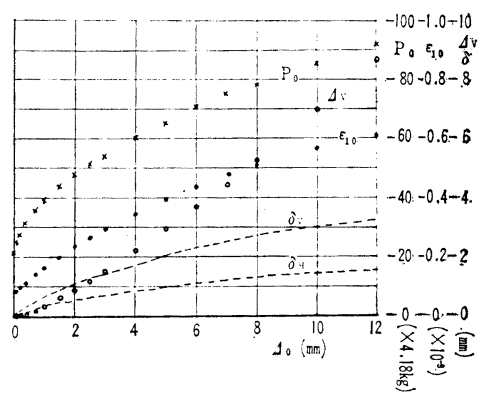
記してある。 $A_{V}$ は管頂の上方への変位, $\delta_{V}$ は管の鉛直 径変化, $\delta_{H}$ は水平半径の增加量, で㤁る。

測定が終了し砂を箱から排出したときのストレィン ゲージの值，すなわら イニシアルからのずれは最大 20 micro 程度である。測定中の計器の安定もよいので,ひず 夕の変化は 3〜 5 micro, 絶対值は 15 micro 程度の精度 で十分決定しうると考えられる。もしら測定值のばらつ きは, 各夷験回ごとの砂のつめ方による砂の状態のばら つきを表現していると思われる。一般に底板全圧力 $P_{0}$ は押上量 $\Delta_{0}$ の増加にと如て急増し, 以降ゆるや かな増加を示すが，ひずみ $\varepsilon$ は全体になだらかな上にら の曲線となることが注目される。それゆえ, 圧力 $P_{0}$ と ひずみにとの間には線形関係が保たれていないと想定さ れ，この点については後述する。

\section{3. パイプの計算一モーメント分布亡管のたわみ}

使用した円管を薄肉円筒と考兵、エネルギー法を用い て応用力学的計算をして数值を代入し，いらいろな外力 条件についてのグラフを描いた。それらの結果をうるに は, 表一1 に式の形で示されたものを組及合わせればよ w。

曲げモーメントを $M=\check{M} w R^{2}$ ，軸力を $T=\widetilde{T} w R$ と 書くと, $\widetilde{M}, \widetilde{T}$ は各々荷重分布の形によって定まる係数 であり, 荷重の大きさにはよらず中心角 $\theta$ の関数であ る。円管の常数を式に代入すると, ひずみはつぎのよう になる。 
表一1パィプの計算結果

\begin{tabular}{|c|c|c|c|c|}
\hline 荷重状態 & $\theta$ の範囲 & 曲げモーメント $\left(w R^{2}\right)$ & 力 $(w R)$ & $\begin{array}{l}\delta_{V} \\
\delta_{H}\end{array}\left(\frac{w R^{4}}{E I}\right)$ \\
\hline & $\alpha \leqslant \theta \leqslant \pi$ & $\frac{1}{\pi}\left(\alpha \sin \alpha+\cos \alpha+\sin ^{2} \alpha \cos \theta-1\right)$ & $\frac{1}{\pi} \sin ^{2} \alpha \cos \theta$ & $\begin{array}{l}-0.01090 \\
+0.01677\end{array}$ \\
\hline पाया $w$ & $\begin{array}{l}0 \leqslant \theta \leqslant \frac{\pi}{2} \\
\frac{\pi}{2} \leqslant \theta=\pi\end{array}$ & $\begin{array}{l}\left(\frac{3}{8}+\frac{1}{\pi}\right)-\sin \theta-\frac{1}{3 \pi} \cos \theta \\
\left(-\frac{1}{8}+\frac{1}{\pi}\right)-\frac{1}{2} \sin ^{2} \theta-\frac{1}{3 \pi} \cos \theta\end{array}$ & $\begin{array}{l}-\frac{1}{3 \pi} \cos \theta-\sin \theta \\
-\frac{1}{3 \pi} \cos \theta-\sin ^{2} \theta \\
\end{array}$ & $\begin{array}{l}\frac{2}{\pi}-\frac{5}{12} \\
\frac{2}{\pi}-\frac{\pi}{4}-\frac{1}{12}\end{array}$ \\
\hline & $\begin{array}{l}0 \leqslant \theta \leqslant \frac{\pi}{2} \\
\frac{\pi}{2} \leqslant \theta \leqslant \pi\end{array}$ & $\begin{array}{l}\left(\frac{1}{6}+\frac{11}{18 \pi}\right)-\frac{1}{4 \pi} \cos \theta-\frac{1}{2} \sin \theta \\
\left(-\frac{1}{6}+\frac{11}{18 \pi}\right)-\frac{1}{4 \pi} \cos \theta-\frac{1}{6} \sin ^{3} \theta\end{array}$ & $\begin{array}{l}-\frac{1}{4 \pi} \cos \theta-\frac{1}{2} \sin \theta \\
-\frac{1}{4 \pi} \cos \theta-\frac{1}{2} \sin ^{3} \theta\end{array}$ & $\begin{array}{l}+0.09715 \\
-0.11011\end{array}$ \\
\hline & $\begin{array}{l}0 \leqslant \theta \leqslant \frac{\pi}{2} \\
\frac{\pi}{2} \leqslant \theta \leqslant \pi\end{array}$ & $\begin{array}{l}\left(\frac{5}{24}+\frac{7}{18 \pi}\right)-\frac{1}{4 \pi} \cos \theta-\frac{1}{2} \sin \theta \\
\left(\frac{1}{24}+\frac{7}{18 \pi}\right)-\frac{1}{4 \pi} \cos \theta-\frac{1}{2} \sin ^{2} \theta+\frac{1}{6} \sin ^{3} \theta\end{array}$ & $\begin{array}{l}-\frac{1}{12 \pi} \cos \theta-\frac{1}{2} \sin \theta \\
-\frac{1}{12 \pi} \cos \theta-\sin ^{2} \theta+\frac{1}{2} \sin ^{3} \theta\end{array}$ & $\begin{array}{l}+0.12280 \\
-0.12200\end{array}$ \\
\hline & & $\frac{1}{4}-\frac{1}{2} \cos ^{2} \theta$ & $-\cos ^{2} \theta$ & $\begin{array}{l}-\frac{1}{6} \\
+\frac{1}{6}\end{array}$ \\
\hline & $\begin{array}{l}0 \leqslant \theta \leqslant \frac{\pi}{2} \\
\frac{\pi}{2} \leqslant \theta \leqslant \pi\end{array}$ & $\begin{array}{l}\frac{1}{8}-\frac{2}{3 \pi} \cos \theta-\frac{1}{2} \cos ^{2} \theta \\
\frac{1}{8}-\frac{2}{3 \pi} \cos \theta\end{array}$ & $\begin{array}{l}-\frac{2}{3 \pi} \cos \theta-\cos ^{2} \theta \\
-\frac{2}{3 \pi} \cos \theta\end{array}$ & $\begin{array}{l}-\frac{1}{12} \\
+\frac{1}{12}\end{array}$ \\
\hline & & $\left(\frac{1}{4}-\frac{2}{9 \pi}\right)-\frac{1}{2} \cos ^{2} \theta+\frac{1}{6} \cos ^{3} \theta$ & $-\cos ^{2} \theta+\frac{1}{2} \cos ^{3} \theta$ & $\begin{array}{l}-0.0950 \\
+0.1090\end{array}$ \\
\hline 最 & & $\frac{1}{8}-\frac{1}{16} \cos \theta-\frac{1}{4} \cos ^{2} \theta+\frac{1}{12} \cos ^{3} \theta$ & $-\frac{1}{16} \cos \theta-\frac{1}{2} \cos ^{2} \theta+\frac{1}{4} \cos ^{3} \theta$ & $\begin{array}{l}-\frac{1}{12} \\
+\frac{1}{12}\end{array}$ \\
\hline
\end{tabular}

（ $\theta$ は最下点からはかった中心角）

$$
\varepsilon=\frac{W}{2.8 \times 10^{3}}\left(\widetilde{M}+\frac{\widetilde{T}}{300}\right) \quad: W=2 w R
$$

同様に, 表一1 に括ける円管のたわ文（直径変化）の係 数を $\tilde{\delta}$ と書くと,

$$
\delta=\frac{W}{2.8} \tilde{\delta}
$$

となる。これらの計算結果は測定值の解析に用いる。

\section{4. 弾性的円管亡非弾性的砂亡の関連}

円管に生じるひずみや変形は荷重分布が与えられれば 計算することができ, 逆にひずみの状態から荷重の様子 を想定することがある程度可能である。しかし, 非弾性 的性質をもつ砂では, 変形から力, 力から変形を知るこ とは応力ーひずみ関係が明瞭ではないので，一般に困難 である。今回の実験のテーマは弾性体と非弾性体の接触 部分に関することが主要なるのであり, 両者が相互に干 渉し合った結果が実測されているわけで, 力学系として は興味あるものである。一つの実際的な関心としては， 力学的性質がよくわかっていて計算に載る円管の beha- vior を観測することによって，比較的性質が不明であ る砂の behavior を推定することが可能ではないか, と いうことがある。そのことはまた, 砂の力学的性質を知 る目的でこのようなタイプの測定器具 (反力係数や横方 向土圧測定用の）が開発されうる可能性をもっている。 たわみ性埋設管を円管と砂とが複合された力学系として とらえてみると, 测定值から計算によって求めた円管の 性質を引き去るなら, 砂の力学的性質が残りとして得ら れることになる。さらに, この研究の出発点である Spangler の理論に関連しては，この理論の創造的であ

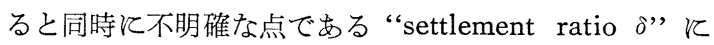
対する一つの接近の道を与える可能性がある。実用上の 改良の道としては $\delta$ 実測する手段が壳られるかもしれ ないということと, 理論面では砂の非弾性的性質を考慮 に入れて, 管の変形と砂の変位との関係を示す何らかの 概念を導入し, settlement ratio と置きかえうるのでは ないか,ということがある。

実験データの整理と解析にあたっては, 以上のような 一般的関係をふまえた上で, 測定值と円管の計算值との 
フィッティングを行なわなければならない。一口でいう なら, 砂が非弾性であることの認識, ということであ る。以下, 砂の反力係数と管への横圧力に焦点をしぼっ て考えてみよう。

円管を薄肉の完全弾性体と考え, 砂が管に执よぼす鉛 直合圧力を $P_{V}$, 水平合圧力を $P_{H}$ とし, 鉛直水平直径 の增加を各々 $\delta_{V}, \delta_{H}$ とする。

$$
\left\{\begin{array}{l}
\delta_{V}=a_{V V} P_{V}+a_{V H} P_{H} \\
{ }^{\delta_{H}}=a_{H V} P_{V}+a_{H H} P_{H}
\end{array}\right.
$$

$a_{i j}$ は $j$ 方向の力によって $i$ 方向に生じる直径増加を与

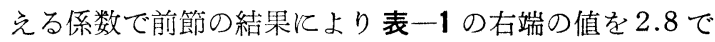
除したるのである。他方, 砂の鉛直 水平方向の反力係 数 (単位の変位に要する力) を各々 $N_{V}, N_{H}$ とすると, 円管が砂中に拥しこまれる量は底板変位 $\Delta_{0}$ と $\delta_{V}$ の和 となり, 水平方向には片側の変位は $\delta_{H} / 2$ であるから,

$$
\left\{\begin{array}{l}
P_{V}=N_{V}\left(\Delta_{0}+\delta_{V}\right) \\
P_{H}=\frac{1}{2} N_{H} \cdot \delta_{H}
\end{array}\right.
$$

となる。砂が非弾性であるから，底板の押し上げにした がって, すなわち $P$ や $\delta$ にしがって $N$ が変化して いくことを考觉ると，底板押上量が $\Delta_{0}$ であるようなあ る砂の状態から,さらに付加的な底板押上量に対応する 砂の状態への微小な变化を考察することが, 砂の力学的 性質を解明するには有利である。そこで, 付加的押上量 $\partial \Delta_{0}$ に対応する各量の変化分に「る」なる記号をつけ, その変化分に対応する反力係数として $n_{V}, n_{H}$ を用いる と，上式はつぎのよろになる。

$$
\begin{aligned}
& \left\{\begin{array}{l}
\partial \delta_{V}=a_{V V} \partial P_{V}+a_{V H} \partial P_{H} \\
\partial \delta_{H}=a_{H V} \partial P_{V}+a_{H H} \partial P_{H}
\end{array}\right. \\
& \partial P_{V}=n_{V}\left(\partial \Delta_{0}+\partial \delta_{V}\right) \\
& \partial P_{H}=\frac{1}{2} n_{H} \partial \delta_{H}
\end{aligned}
$$

各式を $\partial \Delta_{0}$ で除せば，底板変位 $\Delta_{0}$ を独立変数とする力 と変位の刑微分係数の間の関係を表わす式となる。[力一 変位]曲線に括いて， $N$ は原点と各点を結ぶ直線の勾 配であり， $n$ は各点に捇ける接線の勾配となっているこ とに注意する必要があり， $n$ は $\partial N / \partial \Delta_{0}$ ではない。そ れりえ, 暗きょの設計では直接 $N$ が問題となっても, 砂の力学的性質を表琴するのは $n$ の值と $n$ の変化の様 子(例えば $\Delta_{0}$ で表わした関数形) である。

これらの式の中で，荷重分布を推定すれば4つの $a$ は 川管の計算から求为ることができる。 $P_{V}$ の值は底板全 圧 $P_{0}$ (ひずみりングの值）によって与えられるといろ 近似を行なうと, 結局, 4 つの関係式の中浽 5 つの未知 量 $P_{H}, \delta_{V}, \delta_{H}, n_{V}, n_{H}$, があるので, さらに一つの量 を測定するか，一つの関係式を導入しなければ各量を求 めることはできない(10.(2))。

$\frac{\partial P_{V}}{\partial \Delta_{0}}, \frac{\partial P_{H}}{\partial \Delta_{0}}, \delta_{V}, \delta_{H}, n_{V}, n_{H}$, が 4 つの関係式によ
ってどのように結び合わされ, 相互に依存し合っている かをみてみよう。 4 つの式から $\delta_{V}, \delta_{H}$ を消去すると， $n$ を媒介として $P_{V}$ と $P_{H}$ の関係がきまる。

$$
\left\{\begin{array}{l}
\frac{\partial P_{V}}{\partial \Delta_{0}}=n_{V}\left(a_{V V} \frac{\partial P_{V}}{\partial \Delta_{0}}+a_{V H} \frac{\partial P_{H}}{\partial \Delta_{0}}+1\right) \\
\frac{\partial P_{H}}{\partial \Delta_{0}}=\frac{1}{2} n_{H}\left(a_{H V} \frac{\partial P_{V}}{\partial \Delta_{0}}+a_{H H} \frac{\partial P_{H}}{\partial \Delta_{0}}\right)
\end{array}\right.
$$

$\Delta_{0}$ は円管と砂マスとの相対変位を表わすので, $\partial P_{V} /$ $\partial \Delta_{0}, \partial P_{H} / \partial \Delta_{0}$ は見かけ上の鉛直, 水平反力係数のような ものと考えてもよい。図一5 は底板を押し上げると $\partial P_{H}$ $1 \partial \Delta_{0}$ がどの上うに変化するかを $n_{V}$ をパラメーターと して示したものである。同じ目盛で, 計算に用いた $\partial P_{V}$ $1 \partial \Delta_{0}$ (ゆるづめ砂の一例) の值を記入してある（応力分 布の形は後述)。な拓, 同一押上量 $\Delta_{0}$ のとき $n_{V}=n_{H}$ を仮定したときの $n$ の值をこのグラフ上で結んだ線と, その $n$ を用いて求めた $\partial P_{H} / \partial \Delta_{0}$ を参考として破線で記 入してある。後者はつぎの方程式で表わされる。

図一5 側圧の增加率と反力係数の関係

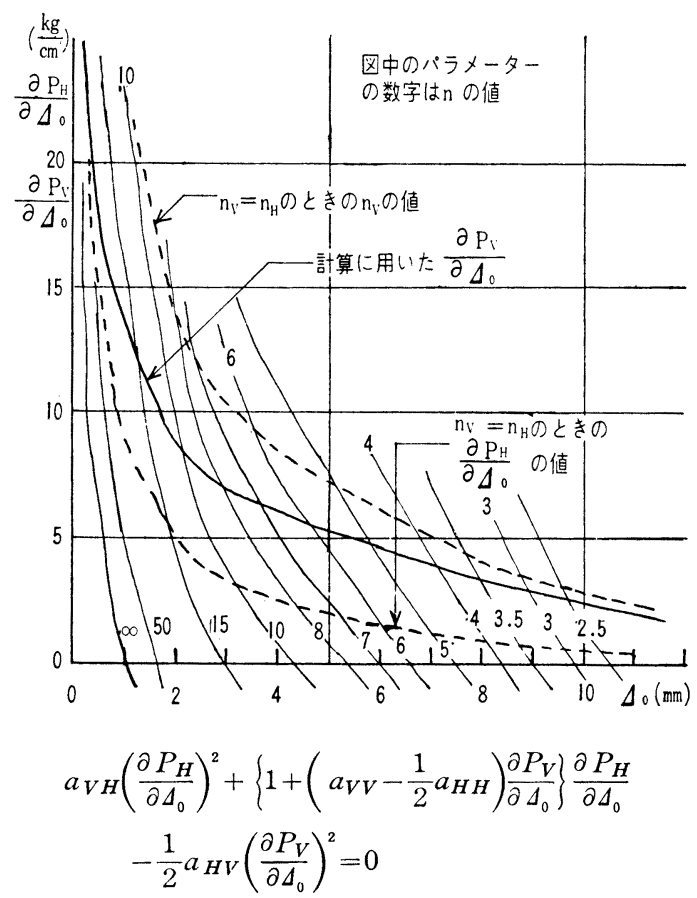

図一5 るみると，まず気づくのは， $n_{V}$ のわずかな変 化が側圧に大きな差を生じることである。現場測定によ り，相当の精度で反力係数の性質を決定できないかぎ り，暗きょの設計は困難である。また， $n$ の值は变位の 增加にしたがって大幅に減少することが予想でき, ある 土について一㑑の $n$ の值を決めることは現実性にとぼ しい。 $n_{H}$ の変化に対しては側圧はそれほど変わらない ので, $n_{V}$ と $n_{H}$ の関係をラフに決めても（例えば $\left.n_{H}=(0.8 \sim 1.5) n_{V}\right)$, 側圧の推定範囲は比較的せまく定 まる。

砂の力学的性質として興味があるのは， $n_{V}$ と $P_{V}$ (ま 
図一6 表一1 より計算した $M^{*}=\frac{M}{w R^{2}}+\frac{T}{w R}$ (ゆるづめ砂)

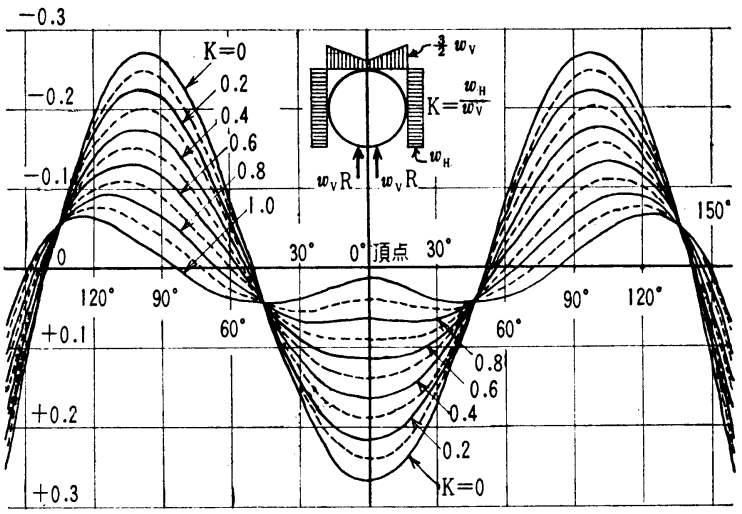

図一7 表一1 より計算した $M^{*}=\frac{M}{w R^{2}}+\frac{T}{w R}$ (かたづめ砂)

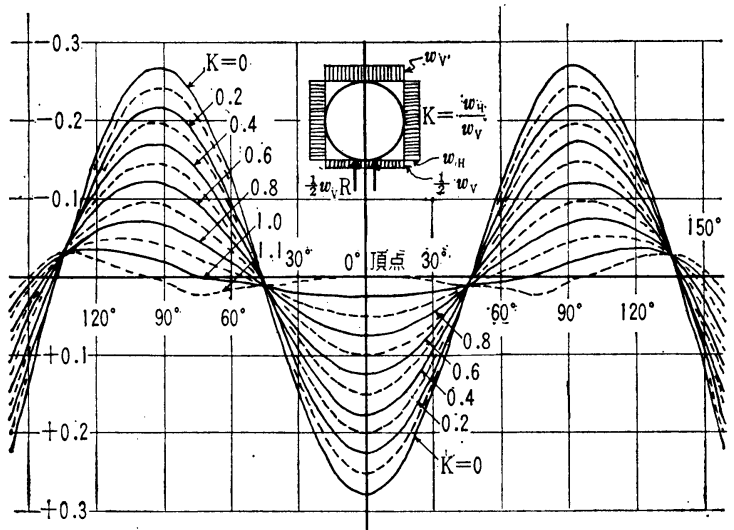

たは $n_{V}$ と $\left.\Delta_{0}+\delta_{V}\right)$ の関係と $n_{H}$ と $P_{H}$ （または $n_{H}$ と $\left.\delta_{H}\right)$ の関係が，どのような類似と差異をるつかにあ り，暗きょ周辺の砂を isotropicとして取り报えるか orthotropic として取り扱わねばならないかを決めるも のである。しかし，同一の圧力に対応する $n_{V}$ と $n_{H}$ が 等しいという仮定（ある $\Delta_{0}$ のとき $n_{V}=n_{H}$ という仮 定ではなく, $P_{V}=P_{H}$ のとき $\left.n_{V}=n_{H}\right)$ の下に 4 つの式 を解くことは繁雑なので, 円管のひずみ分布から横圧力 $P_{H}$ を推定してから検討することにする。

\section{5. 圧力分布形の推定}

薄肉円管に鉛直力 $P_{V}$, 水平力 $P_{H}$ がある仮定された 分布をもって作用する場合に, 円周に生じる fiber strain は 3.の計算結果より次式で与えられる。

$$
\varepsilon=\frac{1}{2.8 \times 10^{3}}\left(P_{V} \widetilde{M}_{V}+P_{H} \widetilde{M}_{H}+\frac{P_{V} \widetilde{T}_{V}+P_{H} \widetilde{T}_{H}}{300}\right)
$$

$\widetilde{M}, \widetilde{T}$ は表一1 中の中心角 $\theta$ の関数で与えられた係数 である。 $P_{H} / P_{V}$ を $K$ とすると

$$
\varepsilon=\frac{P_{V}}{2.8 \times 10^{3}}\left\{\tilde{M}_{V}+\frac{\widetilde{T}_{V}}{300}+K\left(\tilde{M}_{H}+\frac{\widetilde{T}_{H}}{300}\right)\right\}
$$

図一8換籍ひずみ分布（ゆるづめ砂の例）パラメーター は底板変位 $\Delta_{0}$ (単位 $\mathrm{mm}$ )

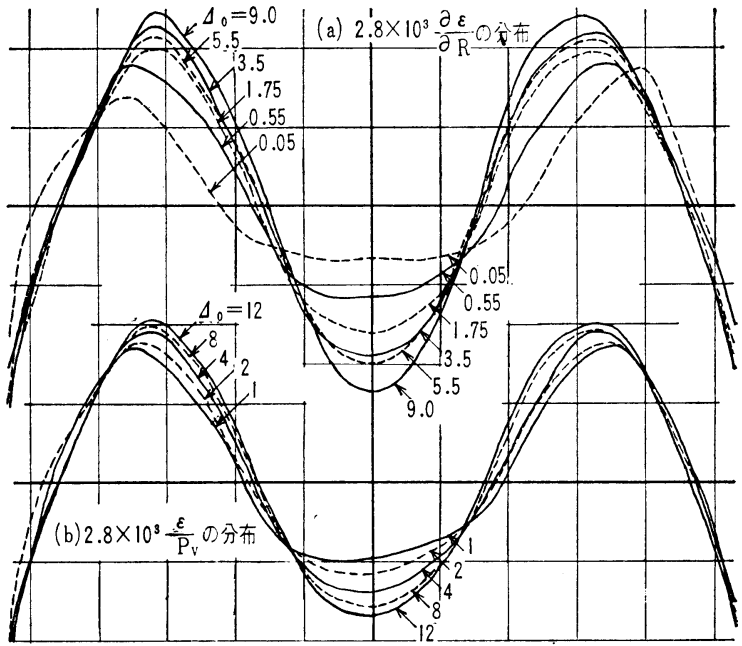

図一9換算ひずみ（かたづめ砂の例）パラメーターは 底板変位 $\Delta_{0}$ (単位. $\mathrm{mm}$ )

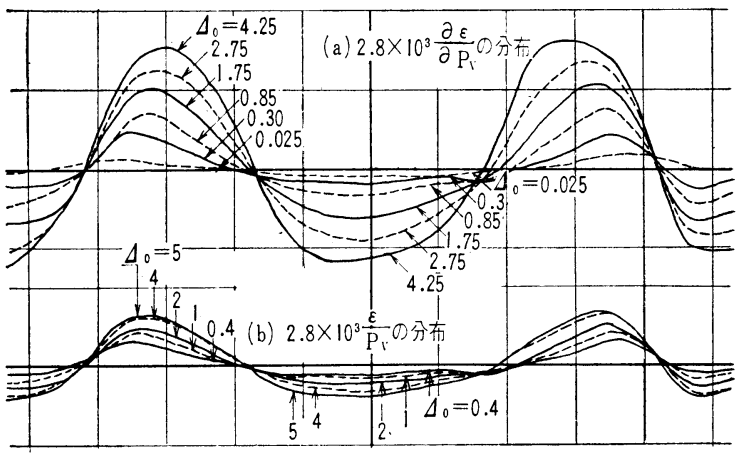

となり，カッコ内を $M^{*}$ と書くと， $M^{*}$ は鉛直水平圧 力の比 $K$ と，压力分布形によって定まる。

そこで,

$$
M^{*}=2.8 \times 10^{3} \frac{\varepsilon}{P_{V}}
$$

の形を用いて， $K$ をパラメーターとした計算值 $M^{*}$ と 測定值 $P_{V}, \varepsilon$ より求めた右辺とを比較し，どのような 圧力分布形が適用しろるかを推定する。これらの結果 を，図一6〜9 亿示す。図一6，7 は表一1上りの計算 值, 図-8はりるづめ砂での実測值の一例, 図一9は かたづめ砂での実測值の一例である。図一8，9の(a) は微少変化分について, すなわち $2.8 \times 10^{3} \times \frac{\partial \varepsilon}{\partial \Delta_{0}} / \frac{\partial P_{V}}{\partial \Delta_{0}}$ の分布とその変化を示すグラフである。グラフはいずれ も円周を直線に伸ばして頂点を中央に最下点を左右端に して描いたものである。

ゆるづめ砂の場合に法計算值と実測值がよく一致して いるが，かたづめ砂の場合には実測值に合致するひずみ 分布を与えるような荷重分布を表一1の組み合せによ。 て得ることは困難であった。それは, fitting を行なう際 
に,つぎの上ろな互いに矛盾する要求をすべて満たすと とができなかったからである（ $\theta$ は最下点からの中心 角)。

(1)（十）最大值に対する ( - ) 最大值の割合

(2) (-) 最大值の生じる位置 (一般飞 $\theta \leq 90^{\circ}$ の点)

(3) $M^{*}=0$ となる位置 $\left(\theta\right.$ が $45^{\circ}$ と $135^{\circ}$ 付近の 2 力 所)

(4) 変曲点の位置（括もに $90^{\circ}<\theta<180^{\circ}$ の箇所） そのために, 頂点付近でよい一致を学る荷重状態と, 側 部付近でよい一致を兄る荷重状態とは違ってくる（後 述)。かたづめ砂の場合には，一般にごく小さな $M^{*}$ の ものを作れる可能性をもち，かつ全体飞矛盾が少ない形 として図一7の分布形を選定した。この分布がもつ最大 の弱点は上述(1)の点にあり, とくに $\Delta_{0}=1 \mathrm{~mm}$ 程度のと き実測值住生じる $(+)$ 最大值と ( - ) 最大值との大き な差治わせることができないことである。本来, 荷重分 布形怔管の変形が増大するにつれ変化するものであるう が，ここで行なったような単純な計算の範囲では fitting の改善を求められないので,以下の解析に招いては図一 6,7 亿示した分布形にもとづくことにする。また， $\theta$ が 小さな円管下部付近では, 計算で仮定した支承条件の狂 いが大きく効いているので，考察の対象外とする。

\section{6. ひずみ分布の測定值亡計算值亡より横圧力 $\boldsymbol{P}_{H}$ の推定}

前節の定性的な考察をとと, 実測值と計算值の量的 な比較を行ない， $M^{*}$ の中にふくまれ るパラメーター $K=P_{H} / P_{V}$ または $k=\partial P_{H} / \partial P_{V}$ を推定する。これによっ て横圧力とその性質を明らかにするこ とはたわみ性円管の設計飞直接役だつ ばかりでなく，4.で導いた式より砂の 力学的 behavior を明らかにする手が かりとなる。

図一6 と図-8, 図一7と図一9を 重祸わせることにより, ゆるづめ砂 かたづめ砂について $k$ 抢よび $K$ が押 上量 $\Delta_{0}$ の增加にともなってどのよう 飞変化しているか調べてみる。結果を

図一-10(a) 底板変位に対する $\boldsymbol{k}=\frac{\partial \boldsymbol{P}_{H}}{\partial \boldsymbol{P}_{V}}$ の変化

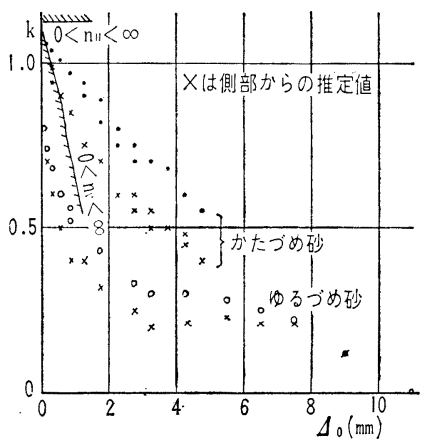

$$
0<n_{H}<\infty: \frac{\partial P_{H}}{\partial P_{V}}<-\frac{a_{H H}}{a_{H V}}
$$

図一10(a) から，変形の進行飞ともなう側圧の性質は つぎのようなものであることがわかる。ゆるづめ砂で は, 鉛直圧力の $80 \%$ 程度からはじまりかなり急速に側 圧の増加割合を減じ，管の変形がすすむ。 $\Delta_{0}=2 \sim 3 \mathrm{~mm}$ 飞達すると $k=0.3$ 程度で一応の安定状態に入り, 以後 ゆるやかとその值を減じ， $\Delta_{0}=10 \mathrm{~mm}$ 以上では注とんど 側圧の增加を期待できない。他方, かたづめ砂では, 初 期の $k$ は 1.1 程度であり, 大きな側圧をうけて管の変形 はきわめて小さい。以後ほぼ直線的に $k$ の值を減じる が, $\Delta_{0}=5 \mathrm{~mm}$ に㨟いても約 $50 \%$ の值を保っている。 実験してはいないが，それ以上の変形に対しては側圧の

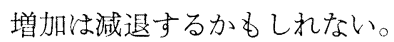

かたづめ砂では，小さな変形に対する側方圧力をかな りくわしく（鉛直圧力の 1.07 1.11），乙か子安定的に 推定できそうである。それに反しゆるづめ砂では，微小 な変位（例克ば管径の $1 / 400$ ，砂かぶりの $1 / 1200$ ） 飞 対しても, 期待しろる側圧は大きく変動（約 $30 \%$ ）す るし，抢そらく施工上のちょっとした差によってこれら の值がかなり影響をうけることが予想される。

実用上の意味が大きい $K$ (側圧と 鉛直圧力そのもの の比）については，図一10(b) と示してある。現状では 砂の挙動が十分解明されていないので, この $K$ の值を 直接設計に用いることはできず， $k$ 亿ついての考察を考 光に入れなければならない。それにもとづいた新しい設

\section{图一10(b) 底板变位に対する} $\boldsymbol{K}=\frac{\boldsymbol{P}_{H}}{\boldsymbol{P}_{V}}$ の変化

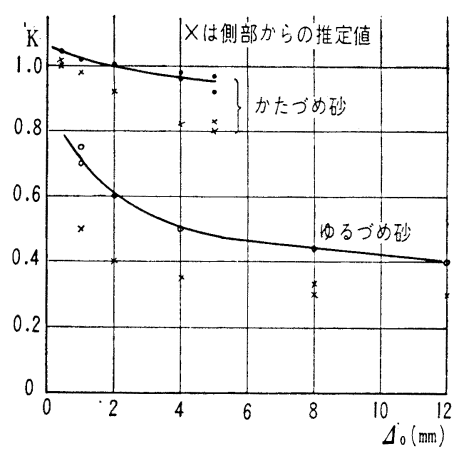

まとめると，kについては図一10(a), $K$ について図 -10(b) の上うになる。前節の扔わりにのべたことを考 慮して, 頂部付近での一致と側分付近での一致とにわけ て記入した。参考のため 4.の式を用いてかたづめ砂に ついて計算し、つぎのような $n$ の限界の線をハッチによ って示す。

$$
0<n_{V}<\infty: \frac{\partial P_{H}}{\partial P_{V}}>-\frac{a_{V V}}{a_{V H}}-\frac{1}{a_{V H} \cdot \frac{\partial P_{V}}{\partial \Delta_{0}}}
$$

計原理が確立されてはじめて, この $K$ の值の実用洒値 がでてくると思われる(8.(4) を参照)。

\section{7. 反力係数 $n_{V}, n_{H}$ の推定}

反力係数を求めるには, 前節で求めた $\partial P_{H} / \partial P_{V}$ を用 いるのと， $\delta_{V} ， \delta_{H}$ の実測值を用いるのと, 二通りのや り方がある。まず，側圧を用いるには 4. で記した式よ $\eta$ 


$$
\left\{\begin{array}{l}
\frac{1}{n_{V}}=\frac{1}{\frac{\partial P_{V}}{\partial \Delta_{0}}}+a_{V V}+a_{V H} \frac{\partial P_{H}}{\partial P_{V}} \\
\frac{1}{n_{H}}=\frac{1}{2}\left(a_{H H}+a_{H} \frac{1}{\frac{\partial P_{H}}{\partial P_{V}}}\right)
\end{array}\right.
$$

図一6,7 の圧力分布を用いるとすると， $a_{i j}$ の值は表一 1 から計算するとつぎのようになる。

$$
\begin{gathered}
\text { ゆるゔめ砂の場合 } \\
\left\{\begin{array} { l } 
{ a _ { V V } = - 0 . 1 0 4 7 0 4 } \\
{ a _ { V H } = + 0 . 0 9 8 1 6 5 } \\
{ a _ { H H } = - 0 . 0 8 3 3 3 3 } \\
{ a _ { H V } = + 0 . 0 8 3 3 3 3 }
\end{array} \quad \left\{\begin{array}{l}
a_{V V}=-0.095501 \\
a_{V H}=+0.093955 \\
a_{H H}=-0.083333 \\
a_{H V}=+0.083333
\end{array}\right.\right.
\end{gathered}
$$

砂が管から受ける変位量は鉛直方向に $\left(\Delta_{0}+\delta_{V}\right)$, 水平 方向に $1 / 2 \delta_{H}$ ではない。なぜなら, 鉛直方向の変位に ついては, 管底は $\Delta_{0}$ 変位し管頂は $\left(\Delta_{0}+\delta_{V}\right)$ 変位する が，管のつぶれを上下対象とすると管側 $\left(\theta=90^{\circ}\right.$ の点) は $\left(\Delta_{0}+1 / 2 \delta_{V}\right)$ 変位することになるからである。水平 方向も，1/2 $\delta_{H}$ ではなく，それを管の鉛直投影面に関 し平均化しなければならない。たわみの関数形は計算に よって求められるが繁雑なので, $\delta$ の分布形を中央に山 のある sinusoidal なものと仮定して平均化を行なう。 管中心から水平方向に座標 $\tau$ をとると管の上半分のたわ みの分布は

$$
\delta^{\prime} V(\tau)=\frac{1}{2} \delta_{V}\left\{1+\cos \left(\frac{\pi \tau}{2 R}\right)\right\} \quad:-R \leq \tau \leq R
$$

で表わせる。底板押上量 $\Delta_{0}$ は管のすべての部分に等し く加わるので, 鉛直方向の砂の変位量 $\Delta_{V}$ はつぎのよう になる。

$$
\Delta_{V}=\Delta_{0}+\frac{1}{R} \int_{0}^{R} \delta^{\prime}{ }_{V}(\tau) d \tau=\Delta_{0}+\left(\frac{1}{2}+\frac{1}{\pi}\right) \delta_{V}
$$

同様の計算を水平方向について行なうと

$$
\Delta_{H}=\frac{1}{\pi} \delta_{H}
$$

\begin{tabular}{|c|c|c|c|c|c|c|c|}
\hline \multirow[b]{2}{*}{$\begin{array}{c}\Delta_{0} \\
\mathrm{~mm}\end{array}$} & \multicolumn{3}{|c|}{ ゆろら゙め砂の例 } & \multicolumn{4}{|c|}{ かたらめ砂の例 } \\
\hline & ${ }_{(\mathrm{kg} / \mathrm{cm})}^{n_{V}}$ & $\Delta_{V}{ }_{(\mathrm{m}}$ & n) ${ }^{\Delta_{H}}$ & $n_{V}^{n_{V} / \mathrm{c}}$ & $\begin{array}{l}n_{H} \\
\text { m) }\end{array}$ & ${ }^{\Delta} V_{(\mathrm{mm}}$ & ${ }_{2}^{\Delta_{H}}$ \\
\hline 0.3 & $\overline{59.2} 69.8$ & 0.097 & 0.070 & 400 & 625 & - & 0.198 \\
\hline 1.25 & 22.3 & 0.557 & 0.239 & 57.8 & 250 & 0.510 & 0.486 \\
\hline 2.25 & 12.7 & 1.157 & 0.380 & 28.6 & 121 & 1.156 & 0.742 \\
\hline 4.5 & 18.4 & 2.730 & 0.621 & 13.6 & 56 & 2.754 & 1.224 \\
\hline 7.5 & $4.4 \quad 14.6$ & 5.071 & 0.856 & & & & \\
\hline 11.0 & 2.3 & 8.050 & 1.041 & & & & \\
\hline
\end{tabular}

となる。これらの平均化を若慮してはじめの式を書き直

\section{し, 数值を代入する。}

<ゆるづめ砂の場合>

$$
\left\{\begin{array}{l}
\frac{1}{n_{V}}=\frac{1}{\frac{\partial P_{V}}{\partial \Delta_{0}}}-0.06120+0.04871 \frac{\partial P_{V}}{\partial P_{V}} \\
\frac{1}{n_{H}}=-0.01895+0.02232 \frac{1}{\frac{\partial P_{H}}{\partial P_{V}}}
\end{array}\right.
$$

<かたづめ砂の場合>

$$
\left\{\begin{array}{l}
\frac{1}{n_{V}}=\frac{1}{\frac{\partial P_{V}}{\partial \Delta_{0}}}-0.05582+0.04871 \frac{\partial P_{H}}{\partial P_{V}} \\
\frac{1}{n_{H}}=-0.01895+0.04272 \frac{1}{\frac{\partial P_{H}}{\partial P_{V}}}
\end{array}\right.
$$

計算結果の概略をまとめると，つぎのようになる。

直径変化の実測值から側圧と反力係数を求めるには簡
単な計算によってなしろる。 $\delta_{V}$ を用いたるのと $\delta_{H}$ を 用いたものと, 招の打の二通り求まる。

$$
\begin{aligned}
& \frac{\partial P_{H}}{\partial \Delta_{0}} \text { (ゆるづめ砂) }: 1.2564 \frac{\partial P_{V}}{\partial \Delta_{0}}+16.80 \frac{\partial \delta_{V}}{\partial \Delta_{0}} \\
& \text { または } 1.1780 \frac{\partial P_{V}}{\partial \Delta_{0}}-16.80 \frac{\partial \delta_{H}}{\partial \Delta_{0}} \\
& \frac{\partial P_{H}}{\partial \Delta_{0}} \text { (かたづめ砂) }: 1.1460 \frac{\partial P_{V}}{\partial \Delta_{0}}+16.80 \frac{\partial \delta_{V}}{\partial \Delta_{0}} \\
& \text { または } 1.1275 \frac{\partial P_{V}}{\partial \Delta_{0}}-16.80 \frac{\partial \delta_{H}}{\partial \Delta_{0}}
\end{aligned}
$$

図-11 砂の変位量と反力係数の関係

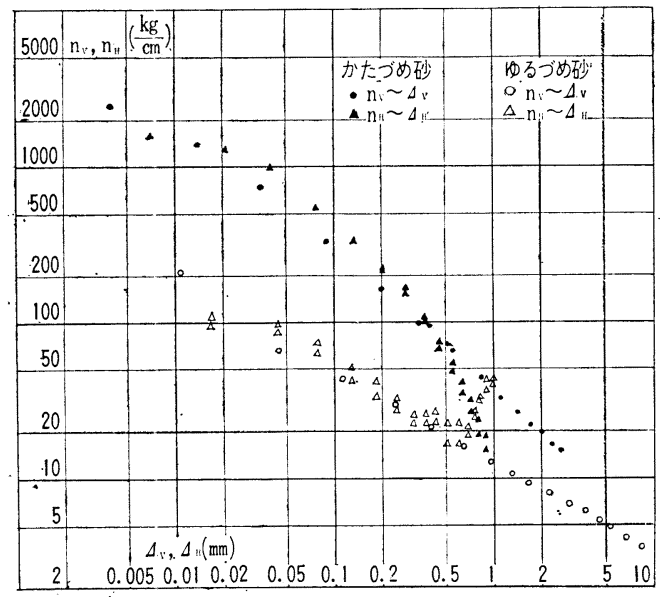

図-12 合圧力と砂の変位の関係

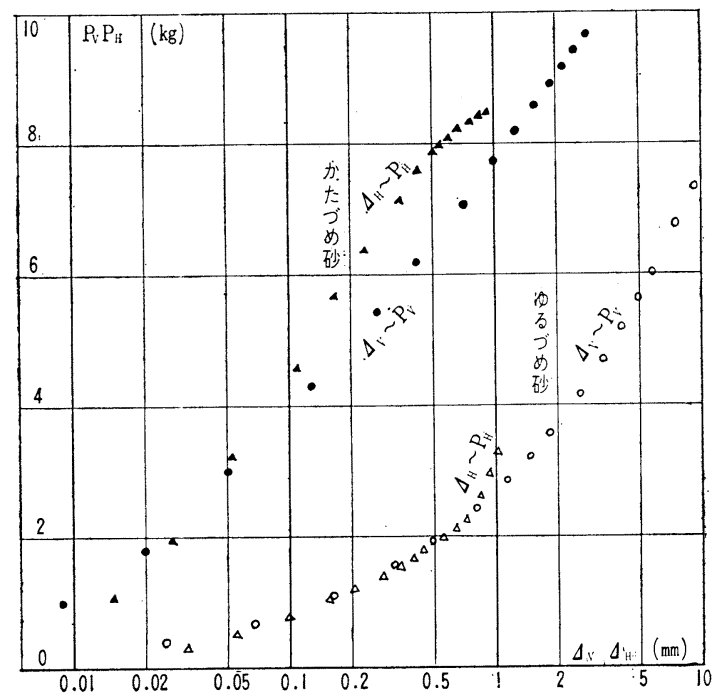




$$
\begin{gathered}
n_{V}=\frac{\partial P_{V}}{\partial \Delta_{V}}=\frac{\frac{\partial P_{V}}{\partial \Delta_{0}}}{1+0.8183 \frac{\partial \delta_{V}}{\partial \Delta_{0}}} \\
n_{H}=\frac{\partial P_{H}}{\partial \Delta_{H}}=-\frac{\frac{\partial P_{H}}{\partial \Delta_{0}}}{0.3183 \frac{\partial \delta_{H}}{\partial \Delta_{0}}}
\end{gathered}
$$

計算結果の弓ち, 平均変位と反力係数の関係（鉛直方 向 $\Delta_{V} \sim n_{V}$, 水平方向 $\left.\Delta_{H} \sim n_{H}\right)$ を両対数目盛で図一11 に, 平均変位と合圧力の関係(同じく $\Delta_{V} \sim P_{V}, \Delta_{H} \sim P_{H}$ ) を半対数目盛で 図一12 に示す。二種の $n_{H}$ の值がプロ ットしてあるのは上述のと打り $\delta_{V}$ を用いたるのと $\delta_{H}$ を用いたものとがあるからで，一般汶 $\delta_{V}$ を用いたもの のほうが大きい。なお，図一11飞括いてりるづめ砂の $n_{H}$ が $A_{H}=0.7 \mathrm{~mm}$ 以降増加に転じている理由は明らかで ない。

\section{8. 実験結果より砂の力学的性質の検討}

砂の締まり具合によって，砂の力学的性質がどのよう 飞影響をろけるかという点を中心に，実験結果をまとめ てみよう。

（1）全般的にいえることは，前の論文でも再三言及 してきたことであるが, 砂密度を $10 \%$ 程度增加させる ことにより, 変位に対していちじるしく鋭感な性質とな る。そして管への圧力, とくに側圧が大きく，乙かも同 一の相対変位を与えた場合, 円管の構造的破壊の指標で ある管の変形量にはそれ注どの差がない。それゆ方砂地 盤での施工では，入念な締固めが必要である。

(2) 側圧 $P_{H}$ の增加割合 $\left(\partial P_{H} / \partial S_{0}\right)$, および $P_{V}$ の 増加割合 $\left(\partial P_{V} / \partial \Delta_{0}\right)$ とそれとの比をみよう(図一10 $\left.(\mathbf{a})\right) 。$ $P_{H}$ \& $P_{V}$ \& その増加率は指数的に減じていくが（例亲 ば図一5)， $P_{H}$ のほうがいちじるしい。かたづめ砂で は, $P_{H}$ の增加率は同一の側方変位量 $\Delta_{H}$ のとき, ゆる づめ砂の約 10〜5 倍の值を示す（図一11 に括いて $A_{H}=$ $0.01 \sim 0.5 \mathrm{~mm}$ )。 $\partial P_{H} / \partial P_{V}$ は 6. で述べたと㧍り, ゆ るづめ砂では圧力増加が期待できる変形初期にその值を 急減させ，側部がやや締った状態で安定した值となる が，そのときには鉛直圧力の増加自体が減少しているの で, 側圧は大きくならない。他方かたづか砂では， $\partial P_{H}$ $d \partial P_{V}$ 変形に対しほぼ直線的に減少していくので, 初 期の側圧増加がかなり期待できる。

（3）破壊にいたるパターンの違いが存在するように 思われる。ゆるい砂では〔管と砂との相対的移動 $\rightarrow$ 管の 変形 $\rightarrow$ 砂中のせん断領域の抎大 $\rightarrow$ 側圧の安定】という各 段階を通って yield するようである。かたづめ砂では， 相対変形が小さい間は鉛直圧力と同程度の側圧が作用 し, 変形が進行すると反力係数が指数的に減じ $\left(\log n_{H}\right.$ は, はじめ $\log \Delta_{H}$ とついで $\Delta_{H}$ と linear な関係), 側 方への破壊, または鉛直水平両方の砂の yield に至るよ
うである。ただし，この最後の点については，与字た相 対変位の最終值が小さい $\left(\Delta_{0}=5 \mathrm{~mm}\right)$ ために明確にされ ていず, 砂の首厚と管の剛性を変えた今後の丰験によっ てかたづめ砂での破噮過程が明らかにされるであらう。

（4）鉛直荷重と水平荷重の比 $P_{H} / P_{V}$ の定量的変化

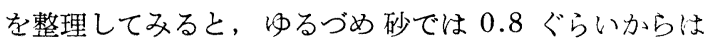
じまり, $\Delta_{0}=4 \mathrm{~mm}$ 以後 $0.5 \sim 0.4$ で安定し, かたつか 砂では 1.05 $\rightarrow 0.95$ に直線に近く減じる（図一10 (b))。 すなわち，かたづめ砂での $P_{H} / P_{V}$ はゆるづめ砂でのそ れの 1.4 倍 $\rightarrow 1.9$ 倍ぐらいの値となる。たわみ性円管 の力学的状態は側圧に大きく依存しているので, この倍 率が埋設管全体としての強度的目安となる。变形の進行 とともにこの音率が増加傾向にあることから設計荷重か ら破壊荷重にいたるまでの荷重汶対しかたづめ砂が高い 信頼度を有していると考えてよい。な招, 現是のかたづ め砂にある埋設管では一般に大きな鉛直荷重が生じやす いかわりに，周囲の砂と管との相対変位はゆるづめ砂の 数分の一であるうこと存考えに入れると，いってう有利 となる。

（5）円管の外力条件と応力状態が砂密度によってど のような差をるっているか座, や队実際的立場からみて みよう。埋設管の設計やその安定性を考える場合に, ゆ るづめ砂とかたづめ砂の奏験結果を比較しようとして も, 相対変位と冈管への外力の生じ方, 砂と管の挙動,

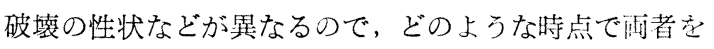
比較するのが適切かが問超となる。すなわち単に底板押 上量 $\Delta_{0}$ の等しいときとか, 鉛直荷重 $P_{V}$ が等しいとき 飞比較するということができない。そこで，管と砂なふ くめた構造物の破壊へのプロセスを考光, 両者が同等之 思われる“段階”に至ったところすなわら yield point のような時点をとりあげてみよう。

図一10(a) より以るづめ砂では $\Delta_{0}=7 \sim 7.5 \mathrm{~mm}$ つ点 をとりだす。かたづめ砂ではこの図からははっきりしな いが，変位に対する敏感さが 2 倍以上であることを考 え, 底板全压力の動きを比較して, 上の点に対応するも のとして $\Delta_{0}=3.5 \sim 4 \mathrm{~mm}$ とする。雨者の比較をつぎの

\begin{tabular}{|c|c|c|c|c|c|c|c|}
\hline & 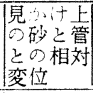 & \begin{tabular}{|l} 
底 板 \\
全圧力
\end{tabular} & $\begin{array}{l}\text { 管頂部の } \\
\text { ひ ナ゙ み }\end{array}$ & $\begin{array}{l}\text { 管側部の } \\
\text { ひナ゙ダ }\end{array}$ & $\begin{array}{l}\text { 宜径 } \\
\text { 変化 }\end{array}$ & $k$ & $K$ \\
\hline 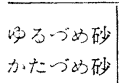 & \begin{tabular}{|l|}
\multicolumn{1}{c}{$\mathrm{mm}$} \\
3.5 \\
3.75
\end{tabular} & $\begin{array}{l}246^{\mathrm{kg}} \\
725^{2}\end{array}$ & $\begin{array}{l}+340 \times 10^{-6} \\
+210 \times 10^{-6}\end{array}$ & $\begin{array}{l}-410 \times 10^{-6} \\
-390 \times 10^{-6}\end{array}$ & $\begin{array}{l}\mathrm{mm} \\
1.71 \\
1.07\end{array}$ & $\begin{array}{l}0.22 \\
0.67\end{array}$ & $\mid \begin{array}{l}0.45 \\
0.97\end{array}$ \\
\hline 洒者の比 & 2.0 & 0.34 & 1.62 & 1.05 & 1.60 & 0.33 & 0.46 \\
\hline
\end{tabular}
ような表にまとめてみる。 推測され，一見たわみ性管の特性を十分生かせない上う に思える。しかし, むしろ逆に構造物の強度は周囲の砂 の安定性に依存しているので, そのような状態のもとで る, 円管忙生じる応力と管径変化は，かたづめ砂のほう が小さくなる。同時飞, $K$ (側圧/鉛直圧) の比より $k$ (側 
圧增加量(鈶直圧增加量）の比が小さいことは，かたづ め砂でまだ側圧增加の余地のあることを示している。こ のことから「ゆるい砂地盤としまった砂地盤に埋設され たたわみ性管が周囲の地盤沈下や盛土の沈下によって大 きな荷重をうけた場合, もし力学的に類似の段階になっ ていても，ゆるづ砂に埋設された管のほうが破壊によ り接近している」と考兄ることができる。しまった砂地 盤は沈下や相対変位量が小さいというだけでなく, 側圧 の安定性に招いてきわめてすぐれている。ただ「砂の相 対密度いかんによって許容変形量を変兄るべきだ」とい う考光方は以上のことだけでは論証不十分であろう。

(6) 反力係数 $n_{V}$ と $n_{H}$ について。ゆるづめ砂で は鉛直方向の変位との関係 $n_{V} \sim \Delta_{V}$, , 水平方向の変位と の関係 $n_{H} \sim \Delta_{H}$ とも, 降伏まで指数的で, そのう兄両 者は同一の $\log -\log$ 直線上飞ある。かたづめ砂の場合, $n_{V} \sim \Delta_{V}$ は指数的だが, $n_{H} \sim \Delta_{H}$ は $\Delta_{H}>1 \mathrm{~mm}$ で $\log$ $n_{H}$ と $\Delta_{H}$ が直線関係にある(図一11)。

（7）砂マスは弾性的ではないので, 砂の性質を反力 係数ということで追求した場合, それが直接圧力と関係 するのか変位と関係するのかという問題は興味深いるの に思える。今回の実験からは, 砂の物理的状態を定式化 しやすい形で $P \sim n$ 関係が反映してはいず（図一12）, 変位量が $n$ を支配していると考兄る立場のほうが解析に 有利であるということができる。常識的に考劣ても, 砂 飞生じた変位（管によって押された量）によって砂の局 部的密度変化や構造的再配列が生じると思われるので, その際そのような状態変化を生じた結果として, 砂が管 に抢上ぼす圧力は変位量を媒介として反力係数と結びっ いていると考觉るほうが，現象の把握には好都合であ る。もちろん，応力とひずみの本質的関係は「鷄と卵」 と同様に一方的因果関係をふくんではいないと考学るの が正しいが，ここに述べたことは，土圧論を変形の立場 から再構成することが何らかの実験的意味をもちはしな いか, という問題提起である。

\section{9. 変形亡圧力, 砂亡管}

結果として今回の実験の主要なテーマとなり,データ を整理する上で興味の中心となったのは砂の変位と圧力 の関係である。すなわち土中の構造物と砂とのかかわり 合いであり,より一般的には「变形を考觉た土圧論」と もいえる。一つの grain として砂がもつ弾性的性質が 粒体の有限変形では全く異なった性質を示すことが明ら かとなった。限界状態江いて砂マスを塑性物体として 取り扱うことはかなりの合理性をるっているが, 過渡状 態ではわずかな変位に対しても砂の力学定数は広範に変 わりうる。 confined compression のように grain to grain の normal pressure が主要なものである場合に は, 近似的に弾性体として解析しうるが, 粒子の相対位
置の有限のずれが現象を支配するものでは無理があるよ う飞思える。それ沖え, 数学的弾性論を砂飞適用する場 合，あくまで付加的微小変形飞対して可能であるのであ って, 累積された変位または累積された圧力と力学的定 数の関係を砂の物性的研究によって明らかにし, それに よって状態変化をつみ重礼てゆく方式をとら效ばならな いであろう。

前論文の中で興味をひいた現象の一つは, 砂中の変位 の状態と圧力の状態が重なり合わないことである。一般 そ, 圧力に関する影響域は小さく, 底板付近限られ, しかも大きな gradient をもっている。他方変位の状況 は，平面的な変化の仕方が一様でなく，砂マスをいくつ かの特徴的部分飞分類しろる。それらは,つぎの 4 つに わけうる。

A. 底板の動きを比較的忠実に表現している底板直上 部の core（場合によっては砂表面に達する柱状 体)

B. 乱れの伝達域で, 等值線図の密なすべり領域

C. 小さな底板変位では変化のとぼしい, 箱の中央に ある砂表面部分

D. $B$ と不変域との中間帯

砂の力学定数が与兄られた外的変位の大きさによってい

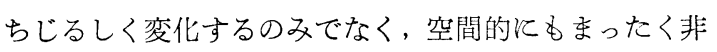
等質に分布していることを示している。問題となる構造 物の境界面に打いても，与えられた条件の中で砂に“定 まらない定数”しか与えない。変位と圧力の関係を示す “定数”の分布々変位や圧力の分布を見くらべることに よって, 変位の状況と圧力の状況の差異を説明しうるよ うなく定数↔変位, 圧力>の関係を定式化することが, 実際面からの追求として考学うる。これを手がかりとし て, 現象の実体的解釈への道が開かれる可能性がある。

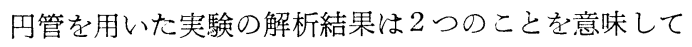
いる。一つ坆管の応力状態から砂の性質を知りうる道が あること, 一つはたわ久性管の強度に効いてくる要素 （たとえば反力係数）と管の剛性によらず効いてくる要 素（たとえば土の圧縮率）とがあるが, 両者は内的関連 をあっていること,である。それゆえ，たわ及性管に関 係のない factor と直結した factor を区別して取り扱っ ても, 砂の性質が解明されないかぎり一般論は展開でき ない。通常の土圧計は土中埋設されたある物体の変化 の様子から土中の状態を推定しょうとするものである が, 壁の変形を制限しようとする立場にあり, 土の性質 を意識的飞考兄に入れ，それをとり入れて利用するとい ろ観点はない。ここでいうのは, 砂が非弾性的性質をる っていることを考虑したうえで, 弾性体と非弾性体がか かわり合う関係から砂の性質を明らかにすることであ る。たわみ性管を設計するさいに求めね就なら始物量 を何にするかということを実際上の問題として追求する 
と同時に，岡性暗きょの設計法にたわみを考えた計算を 付加するのではなく, 構造物と砂で構成される力学系の 設計式（特例として剛性暗きょの設計式を与えるょう な）を求めるということを設計方式の問題として独自に 追求する必要がある。この立場からは, 砂中の状態に焦 点をもった前論文の実験結果はたわみ性管の問題に役立 つものである。

剛性暗きょでは, 外力としての砂の圧力を知れば十分 なわけであるが, 砂にとっての条件は変位の形で与えら れる。この点に括いて, 砂マスが完全弾性体で近似し兄 ないというとらえ方よりも，管の応力状態と砂の変形状 態が one to one correspond していない点に注目する ことが重要な意味をもってくる。砂中の状態が管の応力 を決定しうるとしても, その逆は直接には必ずしもいえ ないからである。

\section{0. 埋設管設計方式への意見}

今回の実験結果と前節の検討にもとついて，まず Spangler の理論へのコメントをなし, 今後の研究の方 向を提示したい。

\section{(1) 側圧の分布形}

管と砂との相対変位の与方が, 室内実験と現場の条 件ではやや違いがあるので, Spangler の示したものと 鉛直圧力の分布形には差がでるかもしれないが, 水平圧 力の分布形には大きな差がないであろうと考えた。結果 は逆で, 彼は parabolic な横圧力を仮定しているが, 中 央に荷重が集中する分布形ではひずみ分布の fitting が ほとんど不可能で, むしろ中央の荷重が小さい形が望ま しい。図一6, 7 の分布形でも, 側部の大きな negative moment に fit させることができないことから, parabolic な仮定恃設計上危険側となる。管の水平たわみ量 の分布は中央部が最大となるにもかかわらず, 砂の反力 がそれに比例していないことになる。この点に招いて も, 反力係数を一定の值とすることへの疑問が生じる。

\section{(2) 反力係数}

鉛直荷重 $P_{V}$, 水平荷重 $P_{H}$ より 水平直径の变化 $\delta_{H}$ は

$$
\hat{o}_{H}=\frac{R^{3}}{E I} d_{H V} \cdot P_{V}-\frac{R^{3}}{E I} d_{H H} \cdot P_{H}
$$

となり, $d_{i j}$ は $j$ 方向の力によって $i$ 方向に生じる管 径変化を求める係数（表一1 右端）で山る。な拓各記号 は符号を正にとる。中心角 $100^{\circ}$ の parabolic 分布では

$$
P_{H}=0.511 R \delta_{H} \epsilon
$$

となる（最大圧力 $=\frac{1}{2} \delta_{H} \epsilon$ として）。これを用いて前 式を書き直すと, Spangler の式をうる。

$$
\delta_{H}=\frac{d_{H V} \cdot P_{V} R^{3}}{E I+0.511 d_{H H}\left(\epsilon R^{4}\right)}
$$

ここで, $d_{H H}=0.1194$ 。.に㨟いて, 4 つの方程式に 5 つの未知数があり, さらに 1 つの量を知るか 1 つの関係
式を導入するかしなければならないと指摘したが，この 式では $\epsilon$ を与えて解決している。 Spangler の考え方の 特色は

$$
p_{H}=\epsilon \cdot \Delta_{H}(\theta) \quad \Delta_{H}(\theta): \text { 水平方向たわみの分布 }
$$

と括き， $\epsilon$ は $P_{V}$ や $\Delta_{H}$ に無関係に土質によって定まる 常数とし， $\Delta_{H}(\theta)$ を parabolic な分布で近似したもの, と考えることができる。 $\Delta_{H}(\theta)$ が parabolic に近似で きて子 $p_{H}(\theta)$ はそろならない。 $\epsilon$ は図一12から明らか なように, 変位量に大きく左右され, $P_{H}$ は $\Delta_{H}$ にでは なくさしろ $\log \Delta_{H}$ と線形関係にあり，彼の仮定は少な くとも砂地盤については無理がある（図一11で $n_{H}$ が 広範囲に変動すること)。現状では, 通常の土質調查と 土質試験を行なって $\epsilon$ を求め, 上式を用いてたわみ性管 の設計をするには困難があり, 地盤の沈下特性や土の圧 縮性，管の剛性などを経験的に勘案して断面決定を行な ろことになる。

\section{(3) 新しい方向}

たわタ性埋設管はく土圧＼cjkstart管の応力>ではなく，変形 を軸にしてその解析を行なわねばならない。

砂の力学的性質括よび，それと管との相互作用に括い て，変形を考慮することがいかに大切かをいままで強調 してきたが，ここで破壊条件に招いて変形が果たす役割 を考えてみよう。3.で行なった計算より，管のたわみ量 と fiber strain は次式で与えられる( $\tilde{\delta}, \tilde{M}$ は表一1の (係数)。

$$
\left(\frac{\delta}{R}\right)=\frac{w}{E I} \tilde{\delta} R^{3}, \quad \varepsilon=\frac{w}{E I} \tilde{M} R^{2} y
$$

$w$ は荷重強度, $E I$ は曲げ剛性, $R$ は半径, $y$ は中立 軸から外縁までの距離である。この両式を比較すると， たわみは半径の 3 乗にひずみは 2 乗に比例するので, 管 径がある值をこえると，たわみが支配的要素となる。あ る荷重状態のとき，管のたわみの弾性限界 $\delta / R=0.02$ (コルゲートパイプの例) と fiber の弾性限界 $\varepsilon=10^{-3}$ $\left(\sigma_{y}=2100 \mathrm{~kg} / \mathrm{cm}^{2}\right.$ に相当）とが同時飞起こるような管 径を求めて夕る。 $\tilde{\delta}=1 / 6, \tilde{M}=1 / 4$ を用い, 雨式の $w /$ (EI) を等置することによって

$$
\left(\frac{y}{R}\right)=\frac{\tilde{\delta} \varepsilon}{\tilde{M}\left(\frac{\delta}{R}\right)}=\frac{1}{30}
$$

をえる。大型コルゲート パイプの波形の y はほぼ 2.5 $\mathrm{cm}$ 程度であるので, $D=1.5 \mathrm{~m}$ 以上ではたわみに対す る弾性限度が先に突破される。弾性限界以上の外力を受 けて変形が進行すると, 局部応力は相対的に緩和し, た わみの増加はむしろ加速されるので, 破壊の状態では変 形について許容值を与えねばならない。コルゲートパ イプでは，通常管径の $5 \%$ のたわみを許している（以 上の考察を敛密に行なうには, 波形のつぶれをも考慮し て，管全体の変形を deflection theory を用いて解かね ばならない)。 
以上の意味の汇かに, 砂が非弾性体であること, 反力 係数は変位の增加とともに急减していくことから，「管 と砂との複合された構造物としての暗きょ」の破壊規準 として管の変形（砂にとっては土圧を mobilize する変 位量）をとる方式は, 十分検討に值すると思う。以下に 述べるものはまだきわめて粗雑なるのであるが, 変形を 主体とした設計法の考光方の例として提起してみたい。

管のたわみ量を $\delta$, 鉛直荷重を $P_{V}=w R$ とすると

$$
-\delta=a \frac{P R^{3}}{E I}
$$

$a$ は表-1の係数。荷重を変位の関数と考觉て

$$
P_{V}=F_{1}\left(\Delta_{V}\right)=F_{1}\left(s-\left(\frac{1}{2}+\frac{1}{\pi}\right) \delta_{V}\right)=F\left(\delta_{V}\right)
$$

と書き ( $s$ は管に対する周囲の土の沈下量), $P_{H} / P_{V}=K$ を用いると

$$
\begin{aligned}
-\delta_{V} & =\left(a_{V V} P_{V}+a_{V H} P_{H}\right) \frac{R^{3}}{E I} \\
& =\frac{12 a_{V V}}{E} F\left(\delta_{V}\right)\left(1+\frac{a_{V H}}{a_{V V}} K\right)\left(\frac{R}{t}\right)^{3}
\end{aligned}
$$

ここで, $a_{V V}=-1 / 10, a_{V H}=1 / 12, R / t=f$ を代入する とつぎの式を壳る。

$$
\delta_{V}=\frac{6}{5 E} F\left(\delta_{V}\right)\left(1-\frac{5}{6} K\right) f^{3}
$$

この式に対して Spangler の式は， $K$ のところに $(\epsilon \delta)$ の関数を招き $F\left(\delta_{V}\right)$ のところに $W$ (鉛直荷重で, 別

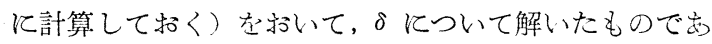
る。この式では逆に, $K$ を一定な值と仮定し, 变位と 圧力の関数形え未知なものとして $F\left(\delta_{V}\right)$ の形で用いて いる。等沈下面 $H_{e}$ や settlement ratioは, せん断力 の mobilization という考光によって $F\left(\delta_{V}\right)$ なる関数形 にふくまれている。

$F\left(\delta_{V}\right)$ の棈造杂明らかにするのが最も重要な仕求とな る。すでに $K$ は明らかにされているので, つぎのよう
な変形を行ない, グラフィカルに解いて， $F\left(\delta_{V}\right)$ の性質 を明らかにしなければならない。

$$
\frac{5 E \delta_{V}}{6\left(1-\frac{5}{6} K\right) f^{3}}=F\left(\delta_{V}\right)
$$

$F\left(\delta_{V}\right)$ は砂の性質に依存しているので, 管のたわみ $\delta_{V}$ より, 平均化した砂の変位 $\Delta_{V}$ に直接関連をもっている と考えられる。そこで, 今回の実験結果から $F_{1}\left(\Delta_{V}\right)$ の 試案を出すとすれば図一12の $\Delta_{V} \sim P_{V}$ を参照にしてつ ぎのようなるのが定性的に合う。

$$
\frac{F\left(\Delta_{V}\right)}{r D H_{1}}=1+\alpha \log \left(1+\beta \Delta_{V}\right)
$$

$\gamma$ 砂の単位体積重量, $D$ は管径, $H_{0}$ は砂高であり, $\alpha$ は $H_{0} / D$ 飞, $\beta$ は砂の性質 (とくに相対密度) によ って定まる。及は8.(1) でふれた敏感度のようなるので ある。 $\alpha$ と $\beta$ を大ざっぱに推定すると,

$$
\begin{array}{lll}
\text { ゆるづめ砂 } & \alpha=2.1 \sim 2.2 & \beta=6 \sim 8 \mathrm{~mm}^{-1} \\
\text { かたづめ砂 } & \alpha=2.9 & \beta=500 \mathrm{~mm}^{-1}
\end{array}
$$

のような值が今回の契験結果からえられる。 $\alpha H_{0} / D$, すなわち管径を単位とする砂高の值に近いと考えられ, $\beta$ は砂が反応す万最小変位量の逆数のような性質がある といろ作業仮説が立てられるように思う。多種類の実験 を行なうのみでなく, 砂の変形機構の実体的解明を行な ううちで, 以上の式（めるいは他の表示）と係数 $\alpha, \beta$ の意味づけがなされねばならない。

謝辞

研究の全過程を通じて, 東京大学 最上武雄教授から 有益な助言と指導をいただいたことを心から感謝し，こ こに扮礼の言葉を述べさせていただく。実験に際しては 東京大学土質研究室の諸氏に执世話になり, 経済的には 富士製鉄の援助を受けた。加藤茂, 吉田喜忠両助手,な らびに富士鉄 宇井允文氏, 土質調査所 森 博氏に深謝す る次第である。

（原稿受付 : 1963.5.8） 